\title{
Trophic state index validation based on the phytoplankton functional group approach in Amazon floodplain lakes
}

Eudes de Oliveira Bomfim, Cleber Nunes Kraus, Maria Tereza M. P. S. Lobo, Ina de Souza Nogueira, Lucas Garcia Magalhães Peres, Geraldo Resende Boaventura, Anne-Elisabeth Laques, Jérémie Garnier, Patrick Seyler, David Motta Marques \& Marie-Paule Bonnet

To cite this article: Eudes de Oliveira Bomfim, Cleber Nunes Kraus, Maria Tereza M. P. S. Lobo, Ina de Souza Nogueira, Lucas Garcia Magalhães Peres, Geraldo Resende Boaventura, AnneElisabeth Laques, Jérémie Garnier, Patrick Seyler, David Motta Marques \& Marie-Paule Bonnet (2019) Trophic state index validation based on the phytoplankton functional group approach in Amazon floodplain lakes, Inland Waters, 9:3, 309-319, DOI: 10.1080/20442041.2019.1570785

To link to this article: https://doi.org/10.1080/20442041.2019.1570785

View supplementary material ¿

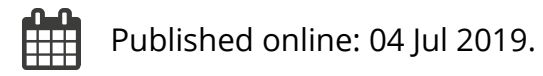

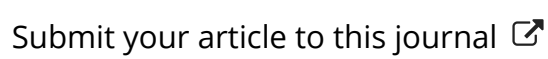

III Article views: 231

Q View related articles $\sqsubset$

View Crossmark data $\nearrow$

Citing articles: 1 View citing articles ¿ 


\title{
Trophic state index validation based on the phytoplankton functional group approach in Amazon floodplain lakes
}

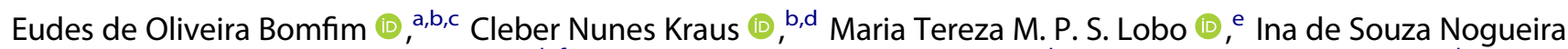

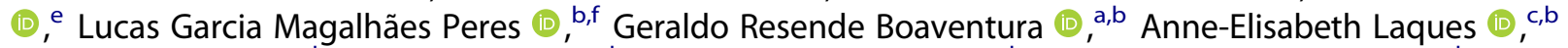

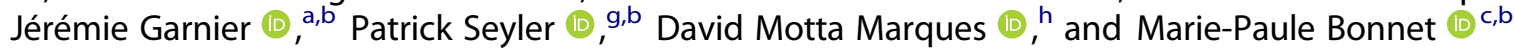

\begin{abstract}
aUniversidade de Brasília, Instituto de Geociências, DF, Brazil; boint International Laboratory LMI OCE "Observatory of Environmental Change”, UnB/IRD, Brasilia, DF, Brazil; 'UMR228 Espace-DEV, French National Research Institute for Sustainable Development (IRD), Montpellier, France;

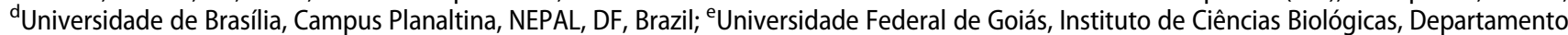
de Botânica, Goiânia, Brazil; fUniversidade de Brasília, Departamento de Geografia, LAGAS, DF, Brazil; ${ }^{9}$ UMR 050 HydroSciences Montpellier

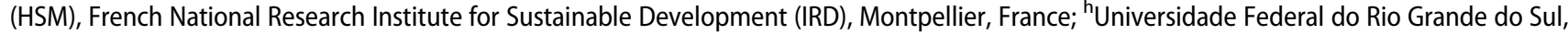
Instituto de Pesquisas Hidráulicas (IPH), Porto Alegre, Brazil
\end{abstract}

\begin{abstract}
Many trophic indices have been constructed for temperate aquatic environments, but few have proved reliable for tropical environments. Indices constructed on the basis of nutrients may not be effective for describing the trophic state because the fractions of nitrogen and phosphorus differ in their potential to predict the nutrient limitation in tropical aquatic environments. We developed an index based on the phytoplankton Reynolds functional groups for an Amazonian floodplain lake from samples collected during 2 contrasting hydrological periods (rising and flushing) and compared it with the index initially proposed by Carlson in 1977 and further adapted to tropical environments by Toledo in 1990. The functional group and Carlson indices matched only $37 \%$ and $56 \%$ of the sample units collected during the rising and flushing periods, respectively. Our study confirms the difficulty of assessing trophic states using only phosphorus and chlorophyll $a$ in tropical floodplain lakes. In this environment (1) nitrogen may significantly limit phytoplankton growth and (2) complex phytoplankton-nutrient relationships occur during the hydrological cycle that cannot be accounted for through a simple phosphorus and chlorophyll $a$ formula.
\end{abstract}

ARTICLE HISTORY

Received 10 July 2017

Accepted 1 January 2019

\section{KEYWORDS}

Amazon wetlands; phytoplankton functional groups; water quality indicators

\section{Introduction}

Freshwater wetlands ensure fundamental services such as flood mitigation, groundwater recharge, water depuration, nutrient and sediment retention, and fish habitat availability (Costanza et al. 1997, Mitsch and Gosselink 2007) and present high levels of biodiversity (Dudgeon et al. 2006). Wetlands declined significantly worldwide in the last century (Gardner et al. 2015) and remain under increasing anthropic pressure (Vörösmarty et al. 2010). In the coming years, Amazonian floodplains will be increasingly threatened by development projects such as dams and river navigation networks, hydrocarbon exploration, and extension of the agricultural frontier (Ferreira et al. 2014, Forsberg et al. 2017, Anderson et al. 2018). These changes may significantly alter water quality, especially suspended solids and nutrient loads, in part by disrupting natural river regimes, which are the principal driver of floodplain characteristics (Junk et al. 2013, Forsberg et al. 2017). Known as "flood pulse," the seasonal hydrological variation ensures water and nutrient renewal enhances matter exchange between aquatic and terrestrial ecosystems, and creates conducive conditions for high productivity and levels of biodiversity. The 4 common hydrological regimes are 2 extreme periods (low water and high water) and 2 intermediate periods (rising and flushing), during which the floodplain lake characteristics differ (Junk et al. 1989). During low-water periods, floodplain lakes present a small volume of highly mixed and turbid water and remain connected to the mainstream (Bourgoin et al. 2007). Rising water levels are ensured by multiple sources of water (runoff from the local drainage basin, direct precipitation, groundwater, and mainstream). The amount of water varies interannually and differs according to floodplain morphology (Lesack and Melack 1995, Bonnet et al. 2008, 2017). Nutrient and water renewal and decay of submerged herbaceous vegetation promote a first peak of primary production 
during the rising period (Junk et al. 1989, Bonnet et al. 2016, Amaral et al. 2018). Higher depth, shorter water residence time, and dilution limit primary production during the high-water period, whereas a second peak of primary production generally occurs during the flushing period (Junk et al. 1989, Bonnet et al. 2016). Extensive cattle ranching and increasing human settlements in the floodplain (Peres et al. 2018) can contribute to nutrient enrichment or changes in their relative proportions and accelerate the eutrophication process (Kraus et al. 2019), which is a serious and increasing problem worldwide (Dodds and Smith 2016).

Primary productivity of phytoplankton can be limited by nutrient availability (Schindler 2012, Paerl et al. 2016). Recent studies in Amazonian lakes (Lopes et al. 2011, Bozelli et al. 2015) and in other Brazilian floodplain systems (Loverde-Oliveira et al. 2012, Padial et al. 2014, Huszar et al. 2015, Machado et al. 2015) have shown that nutrient availability is the most important driver of diversity and in structuring phytoplankton communities. Over the past several decades, many water quality parameter-based or phytoplankton-based indices have been constructed using datasets from temperate regions, yet few have proved reliable for tropical environments. Toledo Júnior (1990) adapted the Carlson (1977) water quality formula for tropical environments, but fractions of nitrogen $(\mathrm{N})$ and phosphorus $(\mathrm{N})$ differ in their potential to predict nutrient limitation in lakes. Total phosphorus (TP) and total soluble $\mathrm{P}$ are equally accurate indicators, whereas dissolved inorganic $\mathrm{N}$ has been shown to be a better predictor of phytoplankton biomass than total nitrogen (TN) or total dissolved $\mathrm{N}$ (Lewis 2011).

Ecologists have proposed approaches based on Reynolds functional groups (RFG) of phytoplankton assemblages based on latitude, trophic states, and morphometric characteristics (Reynolds et al. 2002) to identify simple patterns and predict biological dynamics in freshwaters (Kraus et al. 2018). Many works have updated the Reynolds functional groups. For example, Padisák et al. (2009) consolidated the Reynolds classification and included new groups, and Kruk et al. (2010) proposed a classification based on species morphology. Recently, the latter classification was shown to be most suitable for floodplain environment (Lobo et al. 2018). Padisák et al. (2006) developed the index $Q$, relating phytoplankton assemblage and water quality to lake ecological status. The $Q$ index was successfully applied in various types of environments, for example in a deep Mediterranean reservoir (Becker et al. 2010), deep lakes in southern Alps (Salmaso et al. 2006), and in deep reservoirs in Brazil (Silva and Costa 2015). These studies showed that both ecological indices and the phytoplankton functional approach bring together multiple parameters or characteristics into an indicator capable of representing some type of environmental status. The development of a tool that integrates the 2 approaches could describe the spatial variations of the phytoplankton community in the environment and evaluate the state of this environment because most of the nutrients are typically locked up in phytoplankton cells (Kosten et al. 2012). Following this premise, and to contribute to the international effort for the preservation of these emblematic wetlands, we propose an index to monitor environmental status in floodplain lakes that could support the definition of adapted environmental management policies. In the present study, we developed an index based on the phytoplankton Reynolds functional group approach (denoted $\mathrm{TSI}_{\mathrm{PB}}$ ) to identify spatiotemporal patterns of system dynamics in Amazonian floodplains. We compared it with the well-known categories of trophic states based on nutrients and chlorophyll $a$ (Chl-a). Because the floodplain characteristics vary widely between hydrological phases, the $\mathrm{TSI}_{\mathrm{PB}}$ was built and validated from data collected during distinct periods of the hydrological cycle.

\section{Material and method}

\section{Study site}

We collected samples from the Curuaí floodplain located between $01^{\circ} 50^{\prime}-02^{\circ} 15^{\prime} \mathrm{S}$ and $55^{\circ} 00^{\prime}-56^{\circ} 05^{\prime} \mathrm{W}$ along the right margin of the Amazon River, south of Óbidos city in Pará state, Brazil (Fig. 1). The Curuaí floodplain is a large system composed of several temporally interconnected lakes. The maximum flood extent delimited by lands with altitude $>11.5 \mathrm{~m}$ a.s.l. is $\sim 2500 \mathrm{~km}^{2}$, and it drains several small basins that extend $1500 \mathrm{~km}^{2}$. The lake system is linked with the mainstem by several channels, but only the easternmost channel remains permanently connected (Bonnet et al. 2008). The floodplain is seasonally flooded by water from the Amazon mainstream and also from local drainage basins, seepage, and local precipitation. The high-water period occurs in June and lowwater period in November. The large seasonal water level variation amplitude (average $\sim 6 \mathrm{~m}$ ) combined with flat relief induces a large variation in flood extent between low- and high-water periods. In the Curuaí floodplain, the seasonal water level variation results in a 4-fold variation (from $\sim 500$ to $2500 \mathrm{~km}^{2}$ ) of the open-water extent (Bonnet et al. 2008) along the water year. The river water, rich in inorganic suspended material and nutrients (Sioli 1984, Moquet et al. 2011, Park and Latrubesse 2015), contrasts with the water quality of the other water sources, which are poor in nutrients and rich in organic matter (Bonnet et al. 2016, 2017). 

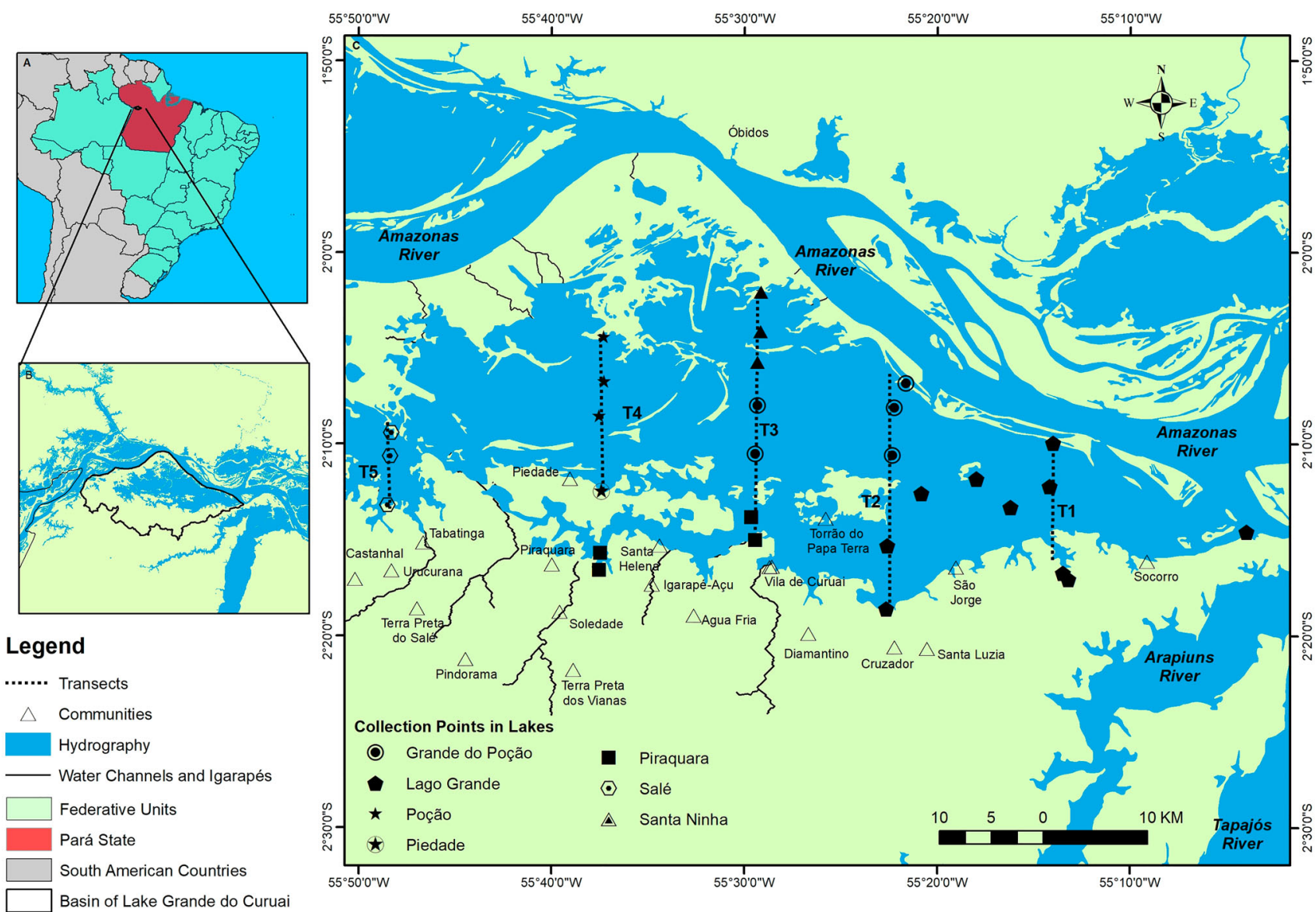

Figure 1. (a) Location of the study site in Brazil; (b) basin of Lake Grande do Curuaí; and (c) sampling stations.

Several small communities with $<100$ families are spread across adjacent uplands and in the tidal regions. A few communities such as Curuaí, Piraquara, and Tabatinga do Salé have a higher density of inhabitants. The population density in the region significantly increased in the last decade (IBGE 2011), augmenting urban cover in the floodplain and adjacent uplands (Peres et al. 2018).

\section{Water quality, biological sampling, and laboratory analysis}

The sampling station distribution was designed to detect heterogeneities among locations and to gather enough replicates for the subsequent analyses (Fig. 1). Stations were distributed among 7 lakes of the Curuaí floodplain. During water sample collection we also reported water level variation in the river (Fig. 2). Sets of 26 and 25 samples were collected in March 2013 (rising period) and September 2013 (flushing period), respectively.

Samples for water quality analysis were collected at the subsurface with a Van Dorn sampler and stored in pre-cleaned plastic bottles with $10 \% \mathrm{HCl}$ and rinsed with Milli-Q water. Three aliquots of $250 \mathrm{~mL}$ were immediately passed through Whatman GF/F glass microfiber filters (porosity $0.7 \mu \mathrm{m}$ ) using a low-pressure vacuum pump; the membranes were wrapped in aluminum foil and frozen for subsequent Chl- $a$ analyses in the laboratory. In addition, an aliquot of $350 \mathrm{~mL}$ was passed through pre-dried and pre-weighed acetate cellulose membranes (pore size $0.45 \mu \mathrm{m}$ ) to obtain total suspended matter concentration. In the laboratory, Chl- $a$ filters were extracted with buffered acetone $(90 \%$ acetone $+10 \%$ saturated magnesium carbonate; Jespersen and Christoffersen 1987), and the extracts were held for $24 \mathrm{~h}$ in the refrigerator before colorimetric determination (APHA 2012). TP was measured on the filtered water by colorimetry (Mackereth et al. 1979), and TN was obtained with a non-dispersive infrared (NDIR) Shimadzu sensor coupled to a Shimadzu carbon analyzer (Shimadzu, Kyoto, Japan).

Quantitative phytoplankton samples were collected at the subsurface and placed directly into dark bottles and preserved with $1 \%$ Lugol's solution. Samples were also concentrated through a plankton net with a mesh diameter of $20 \mu \mathrm{m}$ to aid taxonomic identification when necessary. Phytoplankton was counted at $400 \times$ using an inverted microscope Carl Zeiss, Axioscop 25 model (Thornwood, NY, USA) according to Utermöhl (1958). 


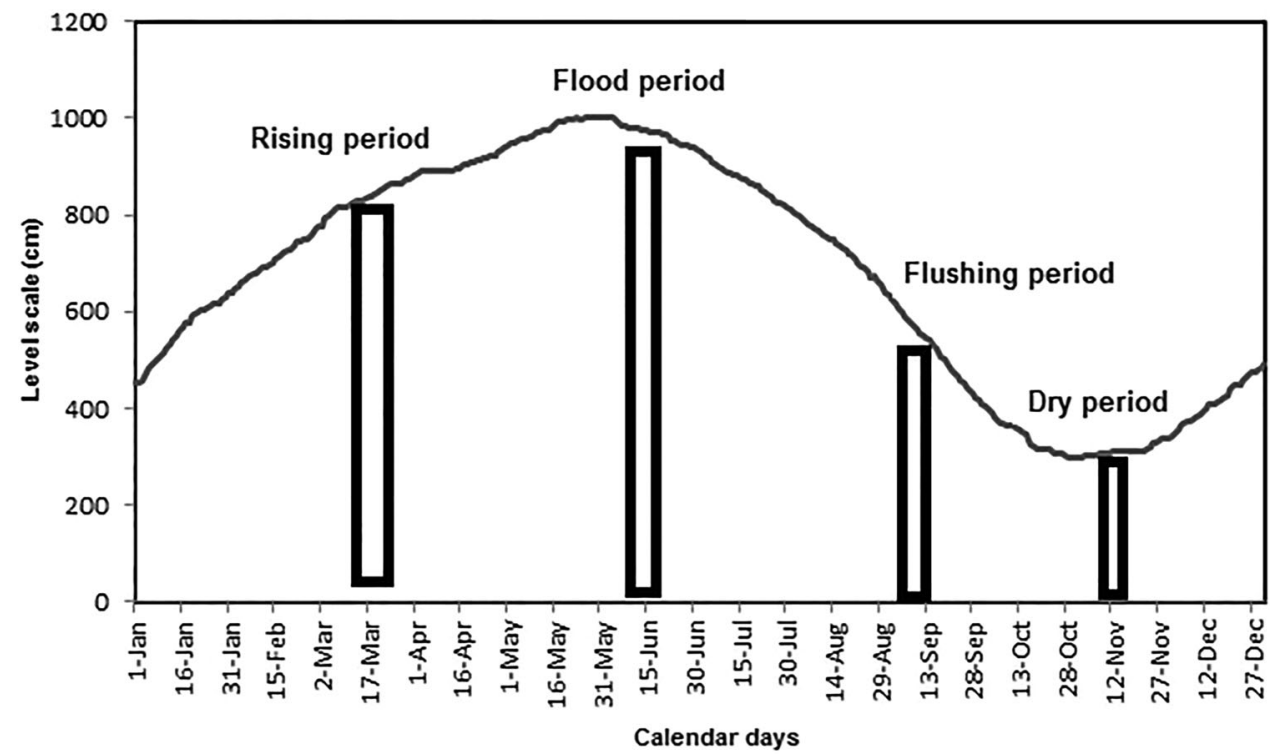

Figure 2. Annual water level variation at the Curuaí gauge in 2006 showing the rising and flushing sampling periods, and the flood and dry periods.

For numerous species, at least 100 individuals were counted according to Lund et al. (1958), and phytoplankton density was expressed as individual units (ind $\mathrm{mL}^{-1}$ ). We used the Van Den Hoek et al. (1995) system to classify the phytoplankton. The algal biovolume was calculated by multiplying the abundance of each species by cell volume average (in $\mathrm{mm}^{3} \mathrm{~L}^{-1}$ ) according to Hillebrand et al. (1999) and Fonseca et al. (2014). The biovolume was converted into biomass assuming $1 \mathrm{~mm}^{3} \mathrm{~L}^{-1}=1 \mathrm{mg} \mathrm{L}^{-1}$ (Wetzel and Likens 2000).

\section{Trophic state indices based on water quality parameters and functional group approach}

We computed the well-known trophic state index based on water quality parameters (denoted $\mathrm{TSI}_{\mathrm{T}}$ hereafter), initially defined by Carlson (1977) and further adapted to tropical environments (Toledo Júnior 1990).

When the sediment load is high, the index calculated from Secchi depth should not be used (Lamparelli 2004). $\mathrm{TSI}_{\mathrm{T}}$ is thus obtained as the arithmetic average of $\mathrm{TSI}_{\mathrm{T}}(\mathrm{Chl}-a)$ and $\mathrm{TSI}_{\mathrm{T}}(\mathrm{TP})$ given by equations 1 and 2 :

$$
\begin{gathered}
\operatorname{TSI}_{\mathrm{T}}(\text { Chl- } a)=10\left[6-\left(\frac{2.04-0.695 \operatorname{lnChl}-a}{\ln 2}\right)\right] \\
\operatorname{TSI}_{\mathrm{T}}(\mathrm{TP})=106-\frac{\ln \left(\frac{80.32}{\mathrm{TP}}\right)}{\ln 2}
\end{gathered}
$$

where Chl- $a$ and TP are concentrations in $\mu \mathrm{g} \mathrm{L}^{-1}$. The limits of the trophic categories defined from $\mathrm{TSI}_{\mathrm{T}}$ values by Toledo Júnior (1990) are included in Supplemental Material 1.
The TSI $_{\mathrm{PB}}$ index was computed from the RFG classification, further consolidated by Padisák et al. (2009) from each sample. The species with biomass contributing to at least $5 \%$ of the biomass in the total sample were selected to identify RFGs (or codon) following Kruk et al. (2002) methodology. Once codons were identified in each sampling unit, we defined trophic categories $\left(F_{\mathrm{cl}}\right)$ as follows: ultraoligotrophic $(\mathrm{UO}) \leq 1.5 ; 1.5<$ oligotrophic $(\mathrm{O}) \leq 2$; $2<$ oligo-mesotrophic $(\mathrm{OM}) \leq 2.5 ; \quad 2.5<$ mesotrophic $(\mathrm{M}) \leq 3 ; 3<$ meso-eutrophic $(\mathrm{ME}) \leq 3.5 ; 3.5<$ eutrophic (E) $\leq 4 ; 4<$ eutro-hypertrophic $(\mathrm{EH}) \leq 4.5$; and $4.5<$ hypereutrophic $(\mathrm{H}) \leq 5$. Finally, to compute $\mathrm{TSI}_{\mathrm{PB}}$, the biomass percentage of each codon was multiplied by the trophic category it indicates. However, some codons were found to be independent from the trophic state, in which case the percentage of the remaining codons was adjusted so that the sum of their respective percentage remained $100 \%$ (equation 3 ):

$$
\operatorname{TSI}_{\mathrm{PB}}=\sum_{i=1}^{n} \frac{\mathrm{b}_{i}}{\mathrm{~B}_{T}} F_{\mathrm{cl}}^{i},
$$

where $b_{i}$ is the biomass of $i$-th RFG, $\mathrm{B}_{T}$ is the sum of biomass at the station, $F_{\mathrm{cl}}^{i}$ is the trophic category indicated by the $i$-th functional group.

\section{Comparison of trophic state indices based on water quality parameters and functional group approach}

We compared the trophic categories indicated by each index by defining a concordance factor (denoted CF hereafter). The $\mathrm{CF}$ value was 1 if both indices gave the 
same trophic category; 0.75 if categories differed by one state (for example if $\mathrm{TSI}_{\mathrm{T}}$ indicated a eutrophic state and $\mathrm{TSI}_{\mathrm{PB}}$ indicated a meso-eutrophic state); 0.5 if categories differed by 2 states (for example if $\mathrm{TSI}_{\mathrm{T}}$ indicated a eutrophic state and $\mathrm{TSI}_{\mathrm{PB}}$ indicated a mesotrophic state); and 0 otherwise.

Multilinear model analysis was undertaken to verify that $\mathrm{TSI}_{\mathrm{PB}}$ correctly reflected the trophic state of the environment, even if it was not directly linked to the variation of a specific nutrient.

\section{Results}

\section{Water quality-based trophic state index $\left(T S I_{T}\right)$}

We report all water quality parameters (minimum, maximum, and median values) from this study (Table 1 ). During both data collection periods, the floodplain lakes were $\sim 4 \mathrm{~m}$ depth and turbid, with a Secchi depth $<0.5 \mathrm{~m}$. TP was relatively high during the rising and flushing periods. The $\mathrm{N}$ to $\mathrm{P}$ mass ratio remained low, with a mean value ranging from 4.3 (standard deviation [SD] 2.7) to 6.6 (SD 5.7) during the rising and flushing periods, respectively. The Chl- $a$ distribution was highly variable among stations, with values $\sim 4$ times higher during the flushing period (Table 1).

During the rising period, $\mathrm{TSI}_{\mathrm{T}}$ values were classified as oligotrophic to hypereutrophic (Table 2). Two stations were classified as oligotrophic: S49 located in a small stream draining the local basin, and S2 located near a margin with shrub vegetation. One station, $\mathrm{S} 10$, was classified as hypereutrophic, influenced by a small stream draining communities and pastures. The remaining stations were classified as eutrophic (16 stations) or mesotrophic (7 stations).

During the flushing period, $\mathrm{TSI}_{\mathrm{T}}$ values in the floodplain ranged from mesotrophic to eutrophic (Table 2). Only one station was categorized as oligotrophic (S31) and 2 stations were considered mesotrophic (S9 and S30). All the others were in the eutrophic category.

\section{Functional groups and phytoplankton based- index $\left(T S I_{P B}\right)$}

Phytoplankton diversity was high with 189 and 198 identified taxa during the rising and flushing periods, respectively (Lobo et al. 2018). The median biomass obtained from the sampling units was 1.0 (SD 0.7) and 4.0 (SD 5.3) $\mathrm{mg} \mathrm{L}^{-1}$ during the rising and flushing periods, respectively (Supplemental Material 2).

During the rising period, we identified 18 RFGs listed in codons C, D, E, F, G, H1, J, Lo, M, MP, N, P, S1, Td, $\mathrm{W} 1, \mathrm{~W} 2, \mathrm{X} 2$, and $\mathrm{Y}$, divided into 44 taxa; the median biomass from sampling units was 1.2 (SD 0.6) $\mathrm{mg} \mathrm{L}^{-1}$. Species, codons, and their biomasses were reported as percentages of the sample total biomass (Supplemental Material 3). Among the identified codons, some can be found regardless of trophic state, and others, like $\mathbf{X} \mathbf{3}$ or $\mathbf{P}$, are encountered only in specific trophic conditions. The latter were considered in computing TSI $_{\mathrm{PB}}$ using the $F_{\mathrm{cl}}$ value attributed to the trophic categories (Table 3).

During the flushing period, we identified the codons F, G, H1, M, MP, N, P, W1, and W2, spread over 32 taxa. While observing a reduction of almost $50 \%$ in the RFG number, species from the cyanobacteria class were dominant, $96.7 \%$ of the species belonged to codons H1, M, and MP. Codon H1 was recorded in $100 \%$ of sample units and was the dominant group in most samples. The codons $\mathbf{M}$ and MP were recorded in $56 \%$ and $24 \%$ of the samples, respectively (Supplemental Material 3). $\mathbf{H 1}$ and $\mathbf{P}$ are representative of eutrophic state and $\mathbf{M}$ is representative of eutrophic-hypereutrophic state $(\mathrm{EH})$. According to $\mathrm{TSI}_{\mathrm{PB}}$, all the stations were eutrophic (E) or in an intermediate status between eutrophic and hypertrophic states (E-H; Table 2).

\section{Comparison between $T S I_{T}$ and $T S I_{P B}$}

During the rising period, the 2 indices $\mathrm{TSI}_{\mathrm{T}}$ and $\mathrm{TSI} \mathrm{IB}_{\mathrm{PB}}$ perfectly matched in only 9 of 24 cases $37 \%$ of the

Table 1. Maximum (Max), minimum (Min), median (Med), and standard deviation (SD) of the water quality variables during rising and flushing periods.

\begin{tabular}{|c|c|c|c|c|c|c|c|c|}
\hline \multirow[b]{2}{*}{ Variables } & \multicolumn{4}{|c|}{ Rising period $(n=26)$} & \multicolumn{4}{|c|}{ Flushing period $(n=25)$} \\
\hline & Min & Max & Med & SD & Min & Max & Med & $\mathrm{SD}$ \\
\hline Depth (m) & 1.7 & 4.7 & 4.0 & 1.5 & 2.5 & 5.1 & 3.7 & 0.7 \\
\hline Secchi (m) & 0.4 & 1.7 & 0.4 & 0.3 & 0.3 & 1.5 & 0.6 & 0.3 \\
\hline $\mathrm{pH}$ & 6.6 & 7.7 & 7.2 & 0.3 & 6.1 & 9.42 & 7.14 & 0.9 \\
\hline TSM (mg L $\left.{ }^{-1}\right)$ & 10.6 & 47.6 & 35.6 & 10.5 & 1.5 & 93.5 & 30.8 & 22.8 \\
\hline $\mathrm{TP}\left(\mu \mathrm{g} \mathrm{L}^{-1}\right)$ & 22.1 & 186.4 & 96.3 & 39.7 & 7.1 & 111.3 & 41.1 & 26.2 \\
\hline $\mathrm{TN}\left(\mu \mathrm{g} \mathrm{L}^{-1}\right)$ & 225.4 & 629.6 & 363.2 & 90.7 & 187.1 & 570 & 276.9 & 104.3 \\
\hline $\operatorname{TIN}\left(\mu \mathrm{g} \mathrm{L}^{-1}\right)$ & - & 249.9 & 89.3 & 58.2 & 10 & 253.2 & 94.5 & 73.3 \\
\hline $\mathrm{NH}_{4}-\mathrm{N}\left(\mu \mathrm{g} \mathrm{L}^{-1}\right)$ & 0.4 & 187.9 & 24.2 & 38.5 & 6 & 183 & 17.5 & 50.3 \\
\hline Chl- $a\left(\mu \mathrm{g} \mathrm{L}^{-1}\right)$ & 0.5 & 203.9 & 7.9 & 39.8 & 9.3 & 157.8 & 28.9 & 39.9 \\
\hline
\end{tabular}

$n=$ number of samples; TSM $=$ total suspended matter; TP = total phosphorus; $\mathrm{TN}=$ total nitrogen, $\mathrm{TIN}=$ total inorganic nitrogen; $\mathrm{Chl}-a=$ chlorophyll $a$; $\mathrm{NH}-\mathrm{N}=$ ammonium-nitrogen. 
Table 2. Trophic state indices based on water quality parameters: $\mathrm{TSI}_{\mathrm{T}}(\mathrm{P})$ using total phosphorus only, $\mathrm{TSI}_{\mathrm{T}}\left(\mathrm{Chl}_{-} a\right)$ using chlorophyll $a$ only, and $\mathrm{TSI}_{\mathrm{T}}$ based on total phosphorus and chlorophyll $a$; phytoplankton based index $\mathrm{TSI}_{\mathrm{PB}}$, trophic state deduced from $\mathrm{TSI}_{\mathrm{PB}}$ (abbreviation in Table 3 and text) and concordance factor (CF) between $\mathrm{TSI}_{\mathrm{T}}$ and $\mathrm{TSI}_{\mathrm{PB}}$.

\begin{tabular}{|c|c|c|c|c|c|c|c|c|c|c|c|c|}
\hline \multicolumn{7}{|c|}{ Rising period } & \multicolumn{6}{|c|}{ Flushing period } \\
\hline Sample unit & $\mathrm{TSI}_{\mathrm{T}}(\mathrm{P})$ & $\mathrm{TSI}_{\mathrm{T}}(\mathrm{Chl}-a)$ & $\mathrm{TSI}_{\mathrm{T}}$ & $\mathrm{TSI}_{\mathrm{PB}}$ & Trophic state & $\mathrm{CF}$ & $\mathrm{TSI}_{\mathrm{T}}(\mathrm{P})$ & $\mathrm{TSI}_{\mathrm{T}}(\mathrm{Chl}-a)$ & $\mathrm{TSI}_{\mathrm{T}}$ & $\mathrm{TSI}_{\mathrm{PB}}$ & Trophic state & $\mathrm{CF}$ \\
\hline 2 & 41.4 & 37.4 & 39.4 & - & - & - & 44.6 & 71.0 & 57.8 & 4.1 & $\mathrm{EH}$ & 0.75 \\
\hline 3 & 57.2 & 38.2 & 47.7 & 3.6 & $E$ & 0.5 & 59.8 & 76.7 & 68.2 & - & - & - \\
\hline 4 & 65.0 & 53.9 & 59.4 & 4.5 & $\mathrm{EH}$ & 0.75 & 55.6 & 76.9 & 66.2 & - & - & - \\
\hline 5 & 64.0 & 68.5 & 66.3 & - & - & - & 52.7 & 66.3 & 59.5 & - & - & - \\
\hline 9 & 62.7 & 57.9 & 60.3 & 3.8 & $E$ & 1 & 48.5 & 53.0 & 50.7 & 3.7 & $E$ & 0.5 \\
\hline 10 & 68.8 & 83.9 & 76.3 & 3.6 & $\mathrm{E}$ & 0.5 & 48.5 & 68.5 & 58.5 & 4 & $\mathrm{E}$ & 1 \\
\hline 11 & 62.6 & 63.2 & 62.9 & 3.5 & $\mathrm{E}$ & 1 & 53.9 & 81.3 & 67.6 & 4 & $\mathrm{E}$ & 1 \\
\hline 12 & 61.4 & 50.4 & 55.9 & 3.2 & $\mathrm{ME}$ & 0.75 & 47.2 & 62.5 & 54.8 & 4.1 & $\mathrm{EH}$ & 0.75 \\
\hline 14 & 62.8 & 46.3 & 54.6 & 4 & $\mathrm{E}$ & 1 & 48.9 & 68.4 & 58.6 & 4 & $E$ & 1 \\
\hline 15 & 64.3 & 45.7 & 55.0 & 4 & $\mathrm{E}$ & 1 & 52.4 & 72.1 & 62.2 & 4 & $\mathrm{E}$ & 1 \\
\hline 16 & 72.1 & 48.3 & 60.2 & - & - & - & 56.6 & 60.0 & 58.3 & 4 & $E$ & 1 \\
\hline 17 & 62.0 & 57.0 & 59.5 & 3.1 & $\mathrm{ME}$ & 0.75 & 59.0 & 63.3 & 61.1 & 3.9 & $E$ & 1 \\
\hline 19 & 62.8 & 54.7 & 58.7 & 3.9 & $E$ & 1 & 62.8 & 72.1 & 67.5 & 4 & $E$ & 1 \\
\hline 22 & 61.1 & 24.2 & 42.6 & 3.8 & $\mathrm{E}$ & 0 & 57.4 & 65.2 & 61.3 & 4.1 & $\mathrm{EH}$ & 0.75 \\
\hline 23 & 64.9 & 51.3 & 58.1 & 3.6 & $E$ & 1 & 64.7 & 58.7 & 61.7 & 4.2 & $\mathrm{EH}$ & 0.75 \\
\hline 24 & 64.9 & 51.3 & 57.4 & 4.1 & $\mathrm{EH}$ & 0.75 & 60.8 & 61.6 & 61.2 & 4.0 & $E$ & 1 \\
\hline 25 & 65.4 & 64.6 & 65.0 & 3.5 & $\mathrm{ME}$ & 0.75 & 49.5 & 59.2 & 54.3 & 4.0 & $E$ & 1 \\
\hline 30 & 61.7 & 44.5 & 53.1 & 3.9 & $\mathrm{ME}$ & 0.75 & 44.9 & 60.4 & 52.6 & 4.0 & $E$ & 0.5 \\
\hline 31 & 58.4 & 45.2 & 51.8 & - & - & - & 25.0 & 61.1 & 43.1 & 4.0 & $\mathrm{E}$ & 0 \\
\hline 33 & 65.4 & 60.0 & 62.7 & 4 & $E$ & 1 & 52.1 & 65.4 & 58.7 & 4.0 & $\mathrm{E}$ & 1 \\
\hline 37 & 48.3 & 47.6 & 48.0 & 3.3 & $\mathrm{ME}$ & 0.75 & 47.1 & 80.6 & 63.8 & 4.1 & $\mathrm{EH}$ & 0.75 \\
\hline 38 & 53.7 & 51.5 & 52.6 & 3.6 & $E$ & 0.5 & 56.2 & 77.2 & 66.7 & 4.0 & $E$ & 1 \\
\hline 39 & 48.5 & 50.1 & 49.3 & 3.0 & $M$ & 1 & 48.1 & 67.3 & 57.7 & 4.1 & $\mathrm{EH}$ & 0.75 \\
\hline 40 & 52.3 & 50.1 & 51.2 & 4 & $\mathrm{E}$ & 0.5 & 49.7 & 60.7 & 55.2 & 4.0 & $\mathrm{E}$ & 1 \\
\hline 41 & 53.2 & 55.9 & 54.6 & 4 & $E$ & 1 & 51.0 & 59.3 & 55.1 & 4.0 & $E$ & 1 \\
\hline 42 & 49.8 & 46.8 & 48.3 & 3.9 & $\mathrm{E}$ & 0.5 & 63.5 & 61.1 & 62.3 & 4.1 & $\mathrm{EH}$ & 0.75 \\
\hline 43 & 51.6 & 49.9 & 50.7 & 3.9 & $\mathrm{E}$ & 0.5 & 48.6 & 73.6 & 61.1 & 4.1 & $\mathrm{EH}$ & 0.75 \\
\hline 45 & - & - & - & - & - & - & 55.1 & 71.3 & 63.2 & 4.0 & $E$ & 1 \\
\hline 49 & 41.4 & 37.4 & 39.4 & 3.6 & ME & 0.75 & 55.0 & 75.2 & 65.1 & - & - & - \\
\hline
\end{tabular}

stations) and differed by more than one category in $29 \%$ of the stations (Table 2). In 11 cases, TSI $_{\mathrm{PB}}$ indicated a higher trophic state than $\mathrm{TSI}_{\mathrm{T}}$. Considering $\mathrm{TSI}_{\mathrm{T}}$ based only on Chl- $a$ or only on TP concentration did not improve index matching (Table 2). According to TSI $\mathrm{PB}_{\mathrm{PB}}$, the trophic state in of most of the sampling stations was eutrophic during the rising period. The scores were relatively better during the flushing period; both indices matched in 56\% and differed by one category in $32 \%$ of the stations, respectively. During this period, Dolichospermum spp. (codon H1), found in eutrophic

Table 3. Codons used to identify the trophic state (among those identified in this study) and corresponding trophic category $F_{\mathrm{cl}}$ value (see text and ESM3). The codon denoted 2, for example, corresponds to 1.5 to 2 , and so on.

\begin{tabular}{|c|c|c|c|c|c|c|c|c|c|}
\hline \multirow[b]{2}{*}{$\begin{array}{l}\text { Codons } \\
\text { state }\end{array}$} & \multicolumn{9}{|c|}{ Trophic category $F_{\mathrm{cl}}$} \\
\hline & $\leq 1.5$ & $\begin{array}{c}2 \\
\text { UO } \\
\end{array}$ & $\begin{array}{c}2.5 \\
0 \\
\end{array}$ & $\begin{array}{c}3 \\
\mathrm{OM} \\
\end{array}$ & $\begin{array}{l}3.5 \\
\mathrm{M}\end{array}$ & $\begin{array}{c}4 \\
\mathrm{ME} \\
\end{array}$ & $\begin{array}{c}4.5 \\
\mathrm{E}\end{array}$ & $\begin{array}{c}5 \\
\mathrm{EH} \\
\end{array}$ & $\mathrm{H}$ \\
\hline $\begin{array}{l}C \\
F\end{array}$ & & & $X$ & & & $x$ & & & \\
\hline G & & & & & & $x$ & & & \\
\hline H1 & & & & & & $x$ & & & \\
\hline M & & & & & & & $x$ & & \\
\hline $\mathbf{P}$ & & & & & & $X$ & & & \\
\hline$T_{D}$ & & & & $x$ & & & & & \\
\hline W2 & & & & & $X$ & & & & \\
\hline X1 & & & & & & & $X$ & & \\
\hline X3 & & $X$ & & & & & & & \\
\hline
\end{tabular}

conditions, represented $>80 \%$ of the biomass at most of the stations. In addition, Microcystis aeruginosa (codon $\mathbf{M}$ ) was present at all stations from the Lago Grande and in some of the lakes, including Grande Poção and Piraquara. Euglena spp. (codon W1) was encountered at station S11, which presented the highest $\mathrm{TSI}_{\mathrm{T}}$ of the floodplain during this period.

The $\mathrm{TSI}_{\mathrm{T}}$ multilinear model was well fitted $\left(\operatorname{adj} R^{2}\right)$ and significant $(p<0.05)$ only for Chl- $a$ and $\mathrm{P}$, demonstrating their direct relationship with these variables, as expected (Table 4). By contrast, the TSI $\mathrm{PB}_{\mathrm{B}}$ multilinear model exhibited no direct relationship with any of the nutrients. It was significantly associated with total suspended matter (Table 4), but the relationship remained weak and negative.

\section{Discussion}

\section{TSI $_{T}$ and $T S I_{P B}$ comparison}

Our results indicated a relatively poor agreement between the $\mathrm{TSI}_{\mathrm{T}}$ index based on TP and Chl- $a$ data and the $\mathrm{TSI}_{\mathrm{PB}}$ index built from functional groups. We could not improve the indices match, even when considering $\mathrm{TSI}_{\mathrm{T}}$ values based only on TP or only on Chl- $a$ data. These results confirm the difficulty in assessing trophic conditions from only a small set of water quality 
Table 4. Multilinear model for trophic state index $\left(\mathrm{TSI}_{\mathrm{T}}\right)$ and phytoplankton based index $\left(\mathrm{TSI}_{\mathrm{PB}}\right)$.

\begin{tabular}{|c|c|c|c|c|c|c|c|c|c|c|}
\hline & \multicolumn{5}{|c|}{$\mathrm{TSI}_{\mathrm{T}}$} & \multicolumn{5}{|c|}{$\mathrm{TSI}_{\mathrm{PB}}$} \\
\hline & Estimate & SE & $t$ value & $p$ & $\operatorname{Adj} R^{2}$ & Estimate & SE & $t$ value & $p$ & $\operatorname{Adj} R^{2}$ \\
\hline (Intercept) & 46.998 & 2.126 & 22.106 & $<0.001$ & 0.66 & 3.957 & 0.104 & 38.036 & $<0.001$ & 0.190 \\
\hline Chl- $a$ & 0.1086 & 0.0179 & 6.069 & $<0.001$ & & - & - & - & - & \\
\hline TP & 0.0965 & 0.0233 & 4.139 & $<0.001$ & & 0.0001 & 0.0012 & 0.068 & 0.946 & \\
\hline TN & -0.0108 & 0.0072 & -1.498 & 0.141 & & -0.0006 & 0.0004 & -1.542 & 0.130 & \\
\hline TSM & -0.0204 & 0.0321 & -0.637 & 0.528 & & -0.0044 & 0.0015 & -2.834 & 0.007 & \\
\hline TIN & 0.0194 & 0.0154 & 1.262 & 0.214 & & 0.0012 & 0.0007 & 1.833 & 0.073 & \\
\hline TON & 0.0112 & 0.0097 & 1.150 & 0.256 & & 0.0007 & 0.0005 & 1.366 & 0.179 & \\
\hline Ammonia & -0.0026 & 0.0182 & -0.141 & 0.888 & & -0.0003 & 0.0009 & -0.358 & 0.722 & \\
\hline
\end{tabular}

$\mathrm{SE}=$ standard error; $\mathrm{Adj} R^{2}=$ adjusted $R^{2}$ of model; $t$-value $=$ significance value of variable and $p$ value $=$ significance value of model $(\leq 0.05$ significant,$\geq 0.05$ not significant).

parameters, as noted in previous studies (Marchetto et al. 2009, Abell et al. 2010), and therefore joint analyses of biological compartments are advisable (Coelho et al. 2007). A complex interplay among hydrology, environment, and organisms through the food web network drives the phytoplankton community in terms of biomass and species in floodplain lakes, which is better reflected in the $\mathrm{TSI}_{\mathrm{PB}}$ index than in the $\mathrm{TSI}_{\mathrm{T}}$ index in the Amazonian floodplain lakes. The $\mathrm{TSI}_{\mathrm{T}}$ index implicitly assumes that TP is the most important driver of phytoplankton biomass and that its combination with Chl- $a$ is enough to predict trophic conditions.

Regardless of the considered hydrological periods, the correlation between TP and Chl- $a$ is generally poor in floodplain lakes; thus, inferring trophic state from these variables is complicated. In turbid waters, such as those encountered in this study, a large amount of the $\mathrm{P}$ is bound to suspended inorganic sediment and is only partly available for biological uptake (Engie and Sarnelle 1990). That TP does not correctly reflect the bioavailable $\mathrm{P}$ may partly explain why $\mathrm{TSI}_{\mathrm{T}}(\mathrm{P})$ is almost systematically greater than $\mathrm{TSI}_{\mathrm{T}}(\mathrm{Chl}-a)$ during the rising period (Table 2). However, $\operatorname{TSI}_{\mathrm{T}}(\mathrm{P})$ is lower than $\mathrm{TSI}_{\mathrm{T}}(\mathrm{Chl}-a)$ in almost all the sampling units during the flushing period, whereas turbidity is comparable between the 2 periods. As noted by Carignan and Vaithiyanathan (1999), a small decrease in $\mathrm{pH}$ along the hydrological cycle may favor the release of a portion of the inorganic-bound $\mathrm{P}$, making it available for biological uptake. Therefore, despite a smaller TP concentration during the flushing period, the bioavailable $\mathrm{P}$ could be higher. But according to Kraus et al. (2019), the proportion of bioavailable $\mathrm{P}\left(\mathrm{PO}_{4}\right)$ during the flushing period is even smaller than during the rising period. Our results during this period are therefore more likely explained by the fact that $\mathrm{P}$ is not the main limiting factor of phytoplankton growth during this period.

In Amazonian floodplain lakes, as in eutrophic environments, relatively low $\mathrm{N}: \mathrm{P}$ may indicate that $\mathrm{N}$ is a limiting factor for phytoplankton growth, which would favor the emergence of atmospheric $\mathrm{N}_{2}$-fixing species
(Visser et al. 2016). As shown in our study, during the flushing period most of the species belonged to the $\mathbf{H 1}$ functional group, with species such as Dolichospermum spp. known for their $\mathrm{N}_{2}$-fixation ability. Thus, indices constructed on the basis of nutrient values are intrinsically linked to 1 or 2 variable predictors and may not be effective in describing the prevailing ecological conditions with respect to the trophic state of floodplain lake environments. Because it is not tied to any specific predictors but instead reflects hydro-environmental-phytoplankton interactions, $\mathrm{TSI}_{\mathrm{PB}}$ more effectively reflects the trophic state of the environment.

We found a significant relationship between the TSI $_{\mathrm{PB}}$ and total suspended matter concentration, but inferring causality is difficult. Controlled experiments and field data suggest that light availability might affect the competitive balance among a large group of shade-tolerant species of phytoplankton (Smith 1986, Scheffer et al. 1997). Furthermore, cyanobacteria proportion can be influenced by a high shade index (Kosten 2012). Even so, our approach seems to be effective. Even if based on functional groups and not on species, the $\operatorname{TSI}_{\mathrm{PB}}$ captures the differences in phytoplankton composition, principally in the cyanobacteria community. Distinct groups of cyanobacteria sensitive to light/shade differences are classified into different functional groups that indicate different types of trophic state. Moreover, the model showed that total suspended matter influence is weak and represents a small portion of $\mathrm{TSI}_{\mathrm{PB}}$, indicating that this influence can be due to the number of sites analyzed, and further applications can exhibit no influence.

\section{Trophic states in the floodplain lakes}

TSI $_{\mathrm{PB}}$ values indicated eutrophic conditions in most of the sampling stations during the rising and flushing periods and a transition toward higher trophic state between the rising to flushing period (Table 2). Affonso et al. (2011) previously reported an increase in trophic state along the hydrological year for the Curuai floodplain, but their $\mathrm{TSI}_{\mathrm{T}}$ computation led to higher trophic state 
than in our study. The increase of the trophic state along the hydrological year was also suggested in Kraus et al. (2019) and reflects the successive influence of river incursion and biogeochemical processes in the floodplain along the hydrological year. During the rising period, the river incursion across the floodplain is the major process that brings nutrients and organic matter into the floodplain (Junk et al. 1989). As discussed, even if only part of these nutrients is available for biological uptake, the inputs satisfy the requirement to sustain a first peak of phytoplankton growth (Moreira-Turcq et al. 2013, Bonnet et al. 2016). Processes that occur in the floodplain participate in maintaining nutrients required for a second peak of phytoplankton during the flushing period (Kraus et al. 2019). Especially, nutrient transfer from the sediment bulk into the water column is ensured by herbaceous plants that pump nutrients from sediments and release them into the water column during their decay (Junk et al. 2010, Bonnet et al. 2016).

\section{Conclusion}

The $\mathrm{TSI}_{\mathrm{T}}$ computation based on the arithmetic average of Chl- $a$ and TP data provided the best agreement with the $\mathrm{TSI}_{\mathrm{PB}}$, yet the agreement between both indices remained relatively weak, perfectly fitting in only $37 \%$ and $56 \%$ of the stations during the rising and flushing periods, respectively. The phytoplankton-based index more adequately described the environment because it captured the complex interplay between hydrological, environmental, and organismal components. Moreover, one source of discrepancy in floodplain lakes could be the phytoplankton growth limitation by $\mathrm{N}$ while $\mathrm{TSI}_{\mathrm{T}}$ only assumed $\mathrm{P}$ limitation. Both indices indicated an increase of the trophic state from the rising to flushing period, suggesting that processes occurring in the floodplains significantly participate in sustaining nutrient requirements for primary production. Our analysis also highlighted some locations with hypereutrophic state in the proximity of margins where organic matter and nutrient enrichment were expected from cattle ranching and domestic effluent. Given the high number and complexity of functional groups in the Curuai floodplain, we were unable to identify ranges of $\mathrm{TSI}_{\mathrm{T}}$ values for specific functional groups, but our analysis showed that $\mathrm{TSI}_{\mathrm{T}}$ values $>55$ in the floodplain lake were mostly associated with specific codon $\mathbf{H} \mathbf{1}$ presence and, to a lesser extent, can also indicate the presence of the codons $\mathbf{M}$ and $\mathbf{M P}$.

\section{Acknowledgements}

This research was done under the auspices of CNPq (Conselho Nacional de Desenvolvimento Científico e Tecnológico,
Brazil), IRD (Institut de Recherche pour le Developpement, grant number 490634/2013-3), LMI OCE (Laboratoire Mixte International Observatoire des Changements Environementaux), and by the Clim-FABIAM research program, which was funded by FRB (French Foundation for Research on Biodiversity, modeling and biodiversity scenario program). The work also received funding from the European Union's Horizon 2020 Research and innovation programme under the Marie Skłodowska - Curie grant agreement No. 691053 (H2020-MSCA-RISE-2015 ODYSSEA project) and from the Bloom-ALERT project (GUYAMAZON program). The first author is grateful to CAPES (Coordenação de Aperfeiçoamento de Pessoal de Nível Superior) in Brazil and $\mathrm{CNPq}$ (400329/2014-0) in France for financial support and PhD grant. We express our sincerest thanks for the Isabelle boat crew and all people from the communities of Curuaí Lake for their kind hospitality for $>5$ years.

\section{Disclosure statement}

No potential conflict of interest was reported by the author(s).

\section{ORCID}

Eudes de Oliveira Bomfim (1D) http://orcid.org/0000-0003-49115039

Cleber Nunes Kraus (DD http://orcid.org/0000-0002-5116-3681 Maria Tereza M. P. S. Lobo (1) http://orcid.org/0000-00026830-2596

Ina de Souza Nogueira (1) http://orcid.org/0000-0002-42206352

Lucas Garcia Magalhães Peres (i) http://orcid.org/0000-00020722-6702

Geraldo Resende Boaventura (1) http://orcid.org/0000-00022707-6633

Anne-Elisabeth Laques (1) http://orcid.org/0000-0003-4469$270 \mathrm{X}$

Jérémie Garnier (1) http://orcid.org/0000-0001-9571-7933

Patrick Seyler (10 http://orcid.org/0000-0003-3390-0614

David Motta Marques (D) http://orcid.org/0000-0002-3809-

8053

Marie-Paule Bonnet (1D http://orcid.org/0000-0002-3950-4041

\section{References}

Abell JM, Özkundakci D, Hamilton DP. 2010. Nitrogen and phosphorus limitation of phytoplankton growth in New Zealand lakes: implications for eutrophication control. Ecosystems. 13(7):966-977.

Affonso AG, Barbosa C, Novo EMLM. 2011. Water quality changes in floodplain lakes due to the Amazon River flood pulse: Lago Grande de Curuaí (Pará). Braz J Biol. 71 (3):601-610.

Amaral JHF, Borges AV, Melack JM, Sarmento H, Barbosa PM, Kasper D, de Melo ML, De Fex-Wolf D, da Silva JS, Forsberg BR. 2018. Influence of plankton metabolism and mixing depth on $\mathrm{CO} 2$ dynamics in an Amazon floodplain lake. Sci Total Environ. 630:1381-1393. 
[APHA] American Public Health Association. 2012. Standard methods for the examination of water and wastewater, 22nd ed. Washington (DC).

Anderson EP, Jenkins CN, Heilpern S, Maldonado-Ocampo JA, Carvajal-Vallejos FM, Encalada AC, Rivadeneira JF. 2018. Fragmentation of Andes-to-Amazon connectivity by hydropower dams. Sci Adv. 4(1):10.1126.

Becker V, Caputo L, Ordóñez J, Marcé R, Armengol J, Crossetti LO, Huszar VLM. 2010. Driving factors of the phytoplankton functional groups in a deep Mediterranean reservoir. Water Res. 44(11):3345-3354.

Bonnet M-P, Barroux G, Martinez JM, Seyler F, MoreiraTurcq P, Cochonneau G, Melack JM, Boaventura GR, Maurice-Bourgoin L, León JG, et al. 2008. Floodplain hydrology in an Amazon floodplain lake (Lago Grande de Curuaí). J Hydrol. 349:18-30.

Bonnet MP, Garnier J, Barroux G, Boaventura GR, Seyler P, Mse CC, Bataillon PE. 2016. Biogeochemical functioning of Amazonian floodplains: the case of Lago Grande de Curuai. In: Pokrovsky OS, Viers J, editors. Riparian zones: characteristics, management practices and ecological impacts. Environmental research advances. Hauppauge (NY): Nova Science; p. 1-14.

Bonnet M-P, Pinel S, Garnier J, Bois J, Resende Boaventura G, Seyler P, Motta Marques D. 2017. Amazonian floodplain water balance based on modelling and analyses of hydrologic and electrical conductivity data. Hydrol Process. 31 (9):1702-1718.

Bourgoin LM, Bonnet M-P, Martinez JM, Kosuth P, Cochonneau G, Moreira-Turcq P, Guyot JL, Vauchel P, Filizola N, Seyler P. 2007. Temporal dynamics of water and sediment exchanges between the Curuaí floodplain and the Amazon River, Brazil. J Hydrol. 335:140-156.

Bozelli RL, Thomaz SM, Padial AAAA, Lopes PM, Bini LM. 2015. Floods decrease zooplankton beta diversity and environmental heterogeneity in an Amazonian floodplain system. Hydrobiologia. 753:233-241.

Carignan R, Vaithiyanathan P. 1999. Phosphorus availability in the Paraná floodplain lakes (Argentina): influence of $\mathrm{pH}$ and phosphate buffering by fluvial sediments. Limnol Oceanogr. 44(6):1540-1548.

Carlson RE. 1977. A trophic state index for lakes. Limnol Oceanogr. 22(2):361-369.

Coelho S, Gamito S, Pérez-Ruzafa A. 2007. Trophic state of Foz de Almargem coastal lagoon (Algarve, South Portugal) based on the water quality and the phytoplankton community. Estuar Coast Shelf Sci. 71(1-2):218-231

Costanza R, Arge R, de Groot R, Farber S, Grasso M, Hannon B, Limburg K, Naeem S, Neill RVO, Paruelo J, et al. 1997. Nature. 387:1-8.

Dodds WK, Smith VH. 2016. Nitrogen, phosphorus, and eutrophication in streams. Inland Waters. 6(2):155-164.

Dudgeon D, Arthington AH, Gessner MO, Kawabata Z-I, Knowler DJ, Lévêque C, Naiman RJ, Prieur-Richard A-H, Soto D, Stiassny MLJ, et al. 2006. Freshwater biodiversity: importance, threats, status and conservation challenges. Biol Rev Camb Philos Soc. 81:163-182.

Engie DL, Sarnelle O. 1990. Algal use of sedimentary phosphorus from an Amazon floodplain lake: implications for total phosphorus analysis in turbid waters. Limnol Oceanogr. 35 (2):483-490.
Ferreira J, Aragão LEOC, Barlow J, Barreto P, Berenguer E, Bustamante M, Gardner TA, Lees AC, Lima A, Louzada J, et al. 2014. Brazil's environmental leadership at risk. Science. 346(6210):706-707.

Fonseca BM, Ferragut, C, Tucci A, Crossetti LO, Ferrari F, Bicudo D de C, Sant'Anna CL, Bicudo CE de M. 2014. Biovolume de cianobactérias e algas de reservatórios tropicais do Brasil com diferentes estados tróficos. [Biovolume of cyanobacteria and algae from tropical reservoirs in Brazil with different trophic states]. Hoehnea. 41:9-30.

Forsberg BR, Melack JM, Dunne T, Barthem RB, Goulding M, Paiva RCD, Sorribas MV, Silva UL, Weisser S. 2017. The potential impact of new Andean dams on Amazon fluvial ecosystems. PLOS ONE. 12(8):e0182254.

Gardner RC, Barchiesi S, Beltrame C, Finlayson C, Galewski T, Harrison I, Paganini M, Perennou C, Pritchard D, Rosenquist A, et al. 2015. State of the world's wetlands and their services to people: a compilation of recent analyses. Note no. 7. Gland (Switzerland): Ramsar Convention Secretariat. SSRN (June).

Hillebrand H, Dürselen C-D, Kirschtel D, Pollingher U, Zohary T. 1999. biovolume calculation for pelagic and benthic microalgae. J Phycol. 35(2):403-424.

Huszar VLM, Nabout JC, Appel M, Santos JBO, Abe DS, Silva LHS. 2015. Environmental and non-spatial processes (directional and non-directional) shape the phytoplankton composition and functional groups in a large subtropical river basin. J Plankton Res. 37:1190-1200.

[IBGE] Instituto Brasileiro de Geografia e Estatística. 2011. Base de informações do Censo Demográfico 2010: resultados do universo por setor censitário. Documentação do Arquivo [Data base of the demographic census 2010: results of the universe by census sector. File documentation]. Rio de Janeiro (Brazil).

Jespersen A-M, Christoffersen K. 1987. Measurements of chlorophyll- $a$ from phytoplankton using ethanol as extraction solvent. Arch Hydrobiol. 109(3):445-454.

Junk WJ, Bayley PB, Sparks RE. 1989. The flood pulse concept in river-floodplain systems. In: Proceedings of the international large river systems Can Spec Publ Fish Aquat Sci. 106; p. 110-127.

Junk WJ, Piedade MTF, Wittmann F, Schongart J, Parolin P. 2010. Amazonian floodplain forests: ecophysiology, biodiversity and sustainable management. New York: Springer.

Junk WJ, Piedade MTF, Lourival R, Wittmann F, Kandus P, Lacerda LD, Bozelli RL, Esteves FA, Nunes da Cunha C, Maltchik L, et al. 2013. Brazilian wetlands: their definition, delineation, and classification for research, sustainable management, and protection. Aquat Conserv Mar Freshw Ecosyst. 24(1):5-22.

Kosten S, Huszar VLM, Bécares E, Costa LS, van Donk E, Hansson LA, Jeppesen E, Kruk C, Lacerot G, Mazzeo N, et al. 2012. Warmer climates boost cyanobacterial dominance in shallow lakes. Global Change Biol. 18:118-126.

Kraus CN, Bonnet M-P, Miranda CA, de Souza Nogueira I, Garnier J, Vieira LCG. 2018. Interannual hydrological variations and ecological phytoplankton patterns in Amazonian floodplain lakes. Hydrobiologia. 830(1):135-149.

Kraus CN, Bonnet, M-P, Nogueira I de S, Lobo MTMPS, Marques D da M, Garnier J, Vieira LCG. 2019. Unraveling flooding dynamics and nutrients' controls 
upon phytoplankton functional dynamics in Amazonian floodplain lakes. Water (Switzerland). 11:154.

Kruk C, Huszar VLM, Peeters ETHM, Bonilla S, Costa L, Lürling M, Reynolds CS, Scheffer M. 2010. A morphological classification capturing functional variation in phytoplankton. Freshwater Biol. 55(3):614-627.

Kruk C, Mazzeo N, Lacerot G, Reynolds CS. 2002. Classification schemes for phytoplankton: a local validation of a functional approach to the analysis of species temporal replacement. J Plankton Res. 24:901-912.

Lamparelli MC. 2004. Grau de trofia em corpos d'água do estado de São Paulo: avaliação dos métodos de monitoramento [Degree of trophy in water bodies in the state of São Paulo: evaluation of monitoring methods] [master's thesis]. São Paulo (SP): University of São Paulo.

Lesack LFW, Melack JM. 1995. Flooding hydrology and mixture dynamics of lake water derived from multiple sources in an Amazon floodplain lake. Water Resour Res. 31(2):329.

Lewis WM. 2011. Rationale for control of anthropogenic nitrogen and phosphorus in inland waters. Environ Sci Technol. 45:10030-10035.

Lobo MTMPS, de Souza Nogueira I, Fabris Sgarbi L, Kraus CN, Bomfim EO de, Garnier J, da Motta Marques D, Bonnet M-P. 2018. Morphology-based functional groups as the best tool to characterize shallow lake-dwelling phytoplankton on an Amazonian floodplain. Ecol Indic. 95: 579588.

Lopes PM, Caliman A, Carneiro LS, Bini LM, Esteves FA, Farjalla V, Bozelli RL. 2011. Concordance among assemblages of upland Amazonian lakes and the structuring role of spatial and environmental factors. Ecol Indic. 11:11711176.

Loverde-Oliveira SM, Pietro-Souza W, Cardoso SJ, FantinCruz I, Mateus LA. 2012. Fatores associados à distribuição espacial do fitoplâncton em lagos de inundação (pantanal norte, Brasil) [Factors associated with the spatial distribution of phytoplankton in floodplain lakes (Pantanal, Brazil)]. Oecol Aust. 16:770-781.

Lund JWG, Kipling C, Le Cren ED. 1958. The inverted microscope method of estimating algal numbers and the statistical basis of estimations by counting. Hydrobiologia. 11(2):143170.

Machado KB, Borges PP, Carneiro FM, de Santana JF, Vieira LCG, de Moraes Huszar VL, Nabout JC. 2015. Using lower taxonomic resolution and ecological approaches as a surrogate for plankton species. Hydrobiologia. 743:255-267.

Mackereth FJH, Heron J, Talling JF. 1979. Water analysis: some revised methods for limnologists. Ambleside (UK): Freshwater Biological Association. 36:120 p.

Marchetto A, Padedda BM, Mariani MA, Lugliè A, Sechi N. 2009. A numerical index for evaluating phytoplankton response to changes in nutrient levels in deep Mediterranean reservoirs. J Limnol. 68(1):106.

Mitsch WJ, Gosselink JG. 2007. Wetlands, 4th ed. Environment. Hoboken (NJ): John Wiley and Sons.

Moquet JS, Crave A, Viers J, Seyler P, Armijos E, Bourrel L, Chavarri E, Lagane C, Laraque A, Casimiro WSL, et al. 2011. Chemical weathering and atmospheric/soil $\mathrm{CO}_{2}$ uptake in the Andean and Foreland Amazon basins. Chem Geol. 287:1-26.

Moreira-Turcq P, Bonnet M-P, Amorim M, Bernardes M, Lagane C, Maurice L, Perez M, Seyler P. 2013. Seasonal variability in concentration, composition, age, and fluxes of particulate organic carbon exchanged between the floodplain and Amazon River. Global Biogeochem Cy. 27:119-130.

Padial AA, Ceschin F, Declerck SAJ, De Meester L, Bonecker CC, Lansac-Tôha FA, Rodrigues L, Rodrigues LC, Train S, Velho LFM, et al. 2014. Dispersal ability determines the role of environmental, spatial and temporal drivers of metacommunity structure. PLOS ONE. 9:e111227.

Padisák J, Borics G, Grigorszky I, Soróczki-Pintér É. 2006. Use of phytoplankton assemblages for monitoring ecological status of lakes within the Water Framework Directive: the assemblage index. Hydrobiologia. 553(1):1-14.

Padisák J, Crossetti LO, Naselli-Flores L. 2009. Use and misuse in the application of the phytoplankton functional classification: a critical review with updates. Hydrobiologia. 621(1):1-19.

Paerl HW, Gardner WS, Havens KE, Joyner AR, McCarthy MJ, Newell SE, Qin B, Scott JT. 2016. Mitigating cyanobacterial harmful algal blooms in aquatic ecosystems impacted by climate change and anthropogenic nutrients. Harmful Algae. 54:213-222.

Park E, Latrubesse EM. 2015. Surface water types and sediment distribution patterns at the confluence of mega rivers: the Solimões-Amazon and Negro Rivers junction. Water Resour Res. 51(8):9127-9140.

Peres LGM, Gurgel H, Laques AE. 2018. Dinâmica da paisagem em planícies de inundação amazônicas: o caso do Lago Grande do Curuai, Pará, Brasil. [Landscape dynamics in Amazon floodplains: a study of Lake Grande do Curuai, Pará, Brazil]. Confins, 35, art. n. 13010.

Reynolds CS, Curuaíszar V, Kruk C, Naselli-Flores L, Melo SS. 2002. Towards a functional classification of the freshwater phytoplankton. J Plankton Res. 24(5):417-428.

Salmaso N, Morabito G, Buzzi F, Garibaldi L, Simona M, Mosello R. 2006. Phytoplankton as an indicator of the water quality of the deep lakes south of the Alps. Hydrobiologia. 563(1):167-187.

Scheffer M, Rinaldi S, Gragnani A, Mur LR, Van Nes EH. 1997. On the dominance of filamentous cyanobacteria in shallow, turbid lakes. Ecology. 78:272-282.

Schindler DW. 2012. The dilemma of controlling cultural eutrophication of lakes. P Roy Soc B. 279:4322-4333.

Silva APC, Costa IAS. 2015. Biomonitoring ecological status of two reservoirs of the Brazilian semi-arid using phytoplankton assemblages (Q index). Acta Limnol Bras. 27(1):1-14.

Sioli H. 1984. The Amazon and its main affluents: hydrography, morphology of the river courses, and river types. In: Sioli H, editor. The Amazon: limnology and landscape ecology of a mighty tropical river and its basin. Dordrecht (Netherlands): Springer; p. 127-165.

Smith VH. 1986. Light and nutrient effects on the relative biomass of blue-green algae in lake phytoplankton. Can J Fish Aquat Sci. 43:148-153.

Toledo Júnior AP. 1990. Informe preliminar sobre os estudos para a obtenção de um índice para a avaliação do estado trófico de reservatórios de regiões quentes tropicais [Preliminary report on the studies to obtain an index for the evaluation of the trophic state of tropical hot-water reservoirs]. São Paulo: CETESB (Brazil); 12 p.

Utermöhl H. 1958. Zur Vervollkommung der quantitative Phytoplankton-Methodik. [Perfecting the quantitative phytoplankton methodology]. Mitt Int Ver Limnol. 9:1-38. 
Van Den Hoek C, Mann DG, Jahns HM. 1995. Algae: an introduction to phycology. Cambridge (UK): Cambridge University Press.

Visser MD, Bruijning M, Wright SJ, Muller-Landau HC, Jongejans E, Comita LS, de Kroon H. 2016. Functional traits as predictors of vital rates across the life cycle of tropical trees. Funct Ecol. 30:168-180.
Vörösmarty CJ, McIntyre PB, Gessner MO, Dudgeon D, Prusevich A, Green P, Glidden S, Bunn SE, Sullivan CA, Liermann CR, et al. 2010. Global threats to human water security and river biodiversity. Nature. 467 (7315):555-561.

Wetzel RG, Likens GE. 2000. Limnological analysis. (Vol. 3). New York: Springer. 